\title{
Virucidal activity of silver nanoparticles against Banana bunchy top virus (BBTV) in banana plants
}

Heba A. Mahfouze ${ }^{1 *}$, Noha K. El-Dougdoug ${ }^{2}$ and Sherin A. Mahfouze ${ }^{1}$

\begin{abstract}
Background: Banana bunchy top virus (BBTV) is a destructive viral disease in many countries including Egypt; it causes severe economic losses in banana crop. Recently, nanotechnology was used to generate resistance against plant viruses. The main purpose of this study was to use silver nanoparticles (AgNPs) as antiviral agents against BBTV. In this research, three different concentrations of AgNPs (40, 50 and 60 ppm) were applied by foliar spray post-BBTV inoculation. In addition, photopigments, oxidative enzymes, proline and phenolic compounds were determined. Besides, Random amplified polymorphic DNA (RAPD) and Sequence-related amplified polymorphism (SRAP) markers were used to evaluate the genotoxicity of AgNPs as antiviral factors against BBTV, compared with the control plants.

Results: In the current study, it was observed that banana plants infected with BBTV and treated with 50 ppm AgNPs have not shown any external symptoms where the rate of infection was 36\%. On the other hand, banana plants treated with 50 ppm AgNPs after viral infection gave a significant increase in dry weight and leaf area, compared with BBTV infected banana plants (viral control). Our study showed that 50 ppm AgNPs treatment post-virus inoculation induced non-significantly and significant changes in chlorophyll ( $a$ and b) and carotenoids, respectively, compared with healthy and nano-controls. In contrast, phenol, proline and oxidative enzymes were significantly increased in all plants treated with 50 ppm AgNPs post-virus inoculation, compared with the healthy control. Our findings observed that the banana plants sprayed with 50 ppm AgNPs after BBTV infection induced a few changes at the genomic DNA level in the banana plants, whereas both RAPD and SRAP markers scored nearly the same polymorphism 36.99 and $37.5 \%$, respectively. So, genotoxicity induced by banana plants treated with 50 ppm AgNPs post-BBTV inoculation was low.

Conclusions: It is evident from the study results the role of AgNPs as a novel, safe and effective antiviral agent against BBTV. These results should be taken into consideration in future for the use of AgNPs for plant viruses management.
\end{abstract}

Keywords: Musa sp., Nanomaterials, Growth parameters, Genotoxicity, Oxidative enzymes, Molecular markers

\section{Background}

Banana (Musa sp.) belongs to Family: Musaceae, it is one of the most important fruit crops and a fundamental food in Egypt and worldwide. Production of banana is

\footnotetext{
*Correspondence: hebaamn@yahoo.com

${ }^{1}$ Genetic Engineering and Biotechnology Research Division, Genetics and Cytology Department, National Research Centre, Dokki 12622, Egypt Full list of author information is available at the end of the article
}

menaced by many viral diseases involving Banana bunchy top virus (BBTV), the most destructive viruses of banana. BBTV infected plants display a rosette or 'bunchy' top and delay the growth of plants. In addition, it induces up to $100 \%$ yield losses (Hu et al. 1996; El-Sayed Eman et al. 2012).

The successful implementation of nanoparticles in medicine has produced some benefits in agri-nanotechnology for plant pathogens resistance (Nair et al. 
2010). Growing nanoscale pathogen-resistant cultivars as natural substitution factors in agriculture environments is the most effective way of disease control. BBTV resistance is a big significance. To protect the plants from the viral infection, the FAO/WHO meeting in 2011 summed up the main affairs of nanoparticle uses in the plant protection. Reports on metal nanomaterials, particularly on those generated with gold or silver, found that nanomaterials display an antiviral activity against several viruses and surely decrease viral infection of cultured cells (Galdiero et al. 2011). Nanomaterials are applied as an antimicrobial agent (antifungal and antibacterial activity). For the virucidal activity, two kinds of metallic nanomaterials are applied; gold nanoparticles (AuNPs) and silver nanoparticles (AgNPs). AgNPs are mainly applied for the virucidal activity against viruses such as Human immunodeficiency virus (HIV-1) (Elechiguerra et al. 2005), Hepatitis B virus (Lu et al. 2008), Influenza virus (Papp et al. 2010) and Herpes simplex virus (Baram-Pinto et al. 2009). For inhibition of viruses, nanomaterials of size ranging from 1 to $100 \mathrm{~nm}$ are predominately applied (Galdiero et al. 2011). It has been observed the reaction between nanoparticles and the virus genome can be altered by modifying the nucleic acid that codes for the viral coat protein. The size of the nanomaterials has a main function in the reaction, smaller the size more the interaction and more inhibition happen. Furthermore, nanomaterials enter the host cell and use their size-dependent phenomenon that induces virucidal activity with their viral genome (RNA or DNA) (Galdiero et al. 2011). Smaller sized nanomaterials enter the host cell and then come in contact with the viral nucleic acid where they block the cellular agents and the viral vectors that aid in the replication of the virus. In addition, they may get linked with the viral genome so that no polymerase activity happens, and no further generation of progeny viruses take place. Besides, capping of AgNPs and AuNPs ensures a higher reaction rather than naked nanomaterials. Capping factors such as surfactants, polymers, and polysaccharides increase the efficiency of nanomaterials (Bryaskova et al. 2011).

The main purpose of this study was to use AgNPs as antiviral agents against BBTV, by foliar spray of BBTV inoculated banana plants with three different concentrations of AgNPs. As well as, growth parameters, photopigments, oxidative enzymes, proline and phenolic compounds were determined. Besides, RAPD and SRAP markers were used to evaluate the effect of AgNPs on DNA damage in treated banana plants, compared with untreated ones.

\section{Methods}

\section{Virus and nanoparticles}

BBTV strain, LC468138 (EL-Dougdoug et al. 2006) was obtained from Virology greenhouse, Agricultural Microbiology Dept., Fac. Agric., Ain Shams Univ. Silver nanoparticles (AgNPs) with size $15 \mathrm{~nm}$ and spherical shape were purchased from Sigma company in a liquid form, it was uniformly foliar-applied at three different concentrations 40, 50 and 60 ppm.

\section{Plant materials}

Healthy tissue culture banana plants cv. 'Grand Nain' were obtained from Horticulture Dept., Fac. Agric., Ain Shams Univ. and were tested for BBTV by DAS-ELISA kit as described by Clark and Adams (1977).

\section{Experimental design}

The soil texture was clay with $\mathrm{pH}$ of 7.38 and Electrical conductivity (EC) of 3.5 collected from the farm of Fac. of. Agric., Ain Shams Univ. The experimental design was a Randomized complete block design with three replicates (ten plants per replicate). (1) Healthy banana plants were sprayed with water (healthy control), (2) BBTV infected banana plants [plants were inoculated by syringe with BBTV as described by Allam et al. (2000)] (viral control), (3) Healthy banana plantlets were individually sprayed with 40, 50 and 60 ppm AgNPs (nano-control). (4) BBTV inoculated banana plants were individually foliar sprayed with 40, 50 and 60 ppm AgNPs after three days from virus inoculation. Recommended irrigation, fertilization, weeding and pest control programs for the banana plants were applied each to treatment having ten banana plantlets. Detection of BBTV infected banana plants was determined by DAS-ELISA kit as described by Clark and Adams (1977). The percentage of BBTV infection was evaluated for three different concentrations of AgNPs.

\section{Plant growth parameters}

After six weeks, dry weight $(\mathrm{g})$ and leaf area $\left(\mathrm{cm}^{2}\right)$, of the third full-sized leaf (from the top) was calculated using the equation = leaf length $(\mathrm{cm}) \mathrm{X}$ leaf width $(\mathrm{cm})$ (Potdar and Pawar 1991). To determine the dry weight, the plants were dried at $70{ }^{\circ} \mathrm{C}$ in the oven for $48 \mathrm{~h}$.

\section{Determination of total phenolic}

Total phenol estimation was carried out according to method described by Daniel and George (1972).

\section{Determination of free proline}

The quantitative free proline was determined (dry weight) according to the method described by Bates et al. (1973). 


\section{Determination of photopigments}

Chlorophyll a, chlorophyll $\mathrm{b}$ and carotenoids were determined according to Vernon and Selly (1966) method.

\section{Plant oxidative enzymes}

The activities of peroxidase (POX) and polyphenol oxidase (PPO) enzymes were determined according to the method described by Matta and Dimond (1963) and Kong et al. (1999).

\section{Extraction of genomic DNA}

Young leaves of treated and untreated banana plants were soaked in liquid nitrogen for DNA extraction using 2\% Cetyltrimethyl ammonium bromide (CTAB) (Borsch et al. 2003; Mahfouze et al. 2018).

\section{Random amplified polymorphic DNA (RAPD) analysis}

A total of five primers were used to amplify DNA (manufactured by Bioneer, New technology certification from ATS Korea) (Table 5). The total reaction mixture was $25 \mu$ contained $10 \times$ PCR buffer, $2 \mathrm{mM} \mathrm{MgCl}_{2}$, $0.2 \mathrm{mM}$ dNTPs mixed, $10 \mathrm{pmol}$ primer, $1.25 \mathrm{U}$ Taq polymerase and about $150 \mathrm{ng}$ genomic DNA. RAPDPCR amplification was performed in a thermal cycler (Biometra Inc., Germany). The temperature profile was as follows: The initial denaturation at $94{ }^{\circ} \mathrm{C}$ for $3 \mathrm{~min}$; followed by 35 cycles of denaturation temperature $94{ }^{\circ} \mathrm{C}$ for $5 \mathrm{~min}$; annealing temperature $37{ }^{\circ} \mathrm{C}$ for $1 \mathrm{~min}$ and extension temperature $72^{\circ} \mathrm{C}$ for $1 \mathrm{~min}$, with a final extension at $72{ }^{\circ} \mathrm{C}$ for $5 \mathrm{~min}$.

\section{Sequence-related amplified polymorphism (SRAP)}

A set of 11 SRAP primers (Table 6) were designed by $\mathrm{Li}$ and Quiros (2001) and used to search for polymorphism among treated and untreated banana plants. The total reaction mixture was $25 \mu \mathrm{l}$ contained 10X PCR buffer, $2 \mathrm{mM} \mathrm{MgCl}, 0.2 \mathrm{mM}$ dNTPs mixed, $10 \mathrm{pmol}$ primers, $1.25 \mathrm{U}$ Taq polymerase and about $150 \mathrm{ng}$ genomic DNA. The amplification regime followed the recommendation of $\mathrm{Li}$ and Quiros (2001) as follows: An initial denaturing step was performed at $94{ }^{\circ} \mathrm{C}$ for $5 \mathrm{~min}$, followed by 5 cycles at $94{ }^{\circ} \mathrm{C}$ for $1 \mathrm{~min}, 35^{\circ} \mathrm{C}$ for $1 \mathrm{~min}$ and $72{ }^{\circ} \mathrm{C}$ for $1 \mathrm{~min}$, subsequently followed by 35 cycles at $94{ }^{\circ} \mathrm{C}$ for $1 \mathrm{~min}, 50{ }^{\circ} \mathrm{C}$ for $1 \mathrm{~min}$ and $72{ }^{\circ} \mathrm{C}$ for $1 \mathrm{~min}$, the final extension step at $72{ }^{\circ} \mathrm{C}$ for $7 \mathrm{~min}$.

Amplification products were separated on a $1.5 \%$ agarose gel containing $1 \mathrm{X}$ TBE buffer $(89 \mathrm{mM}$ Tris- $\mathrm{HCl}$, $89 \mathrm{mM}$ boric acid, $2.5 \mathrm{mM}$ EDTA, pH 8.3) at $90 \mathrm{~V}$. The genomic DNA was stained with RedSafe Nucleic Acid Staining Solution $(1 / 20,000)$ (iNtRON Biotechnology,
Inc. $\mathrm{Kr}$ ). Gels were analyzed by UVI Geltec version 12.4, 1999-2005 (USA).

\section{Statistical analysis}

A Randomized complete block design with three replicates was used. Data of the experiments were exposed to statistical analysis using two-way analysis of variance (ANOVA) (Snedecor and Cochran 1980), where the means separation was carried out using Duncan (1980) multiple range tests and compared using L.S.D test at 0.05 probability level significance was determined at $P<0.05$.

\section{Results}

The reaction of BBTV strain with AgNPs concentrations on tested banana plants

Banana plants were foliar-applied with three different concentrations of AgNPs after BBTV inoculation, the plants reacted with different systemic symptoms ranged from latent $(50 \mathrm{ppm})$ to mild (40 and $60 \mathrm{ppm})$, compared with the viral control (dark green color and form a "hook" shape, on the midrib, reduced size, brittle of the leaves and gather at the top of the plant making a rosetting shape) as are shown in Fig. 1 and Table 1 . The rate of BBTV infection was 63,35 and $45 \%$, using 40,50 and 60 ppm AgNPs, respectively (Table 1). These results were confirmed by DAS-ELISA using specific polyclonal antibodies for BBTV. On the other hand, 60 ppm AgNPs concentration showed phytotoxicity on the banana plants (Fig. 1).

\section{Determination of plant growth parameters}

Treatment with AgNPs post-BBTV inoculation led to a significant increase in the growth parameters (dry weight and leaf area), compared with BBTV infected only banana plants (viral control). On the contrary, the plants treated with $50 \mathrm{ppm}$ AgNPs post-virus inoculation induced nonsignificant and significant effects in the dry weight and leaf area, respectively, compared with the healthy control. Furthermore, viral control was significantly reduced in the growth parameters, compared with the healthy and nano-controls (Table 2).

\section{Photosynthetic pigments}

The banana plants treated with three different concentrations of AgNPs post-BBTV inoculation showed different responses on the process of photosynthesis after 30 days of treatment, whereas 50 ppm AgNPs treatment post-virus inoculation led to non-significant changes in chlorophyll a and b, compared to the healthy control. Furthermore, the content of carotenoids was significantly increased in the plants treated with 40 and $50 \mathrm{ppm}$ AgNPs after virus inoculation. On the contrary, $60 \mathrm{ppm}$ 


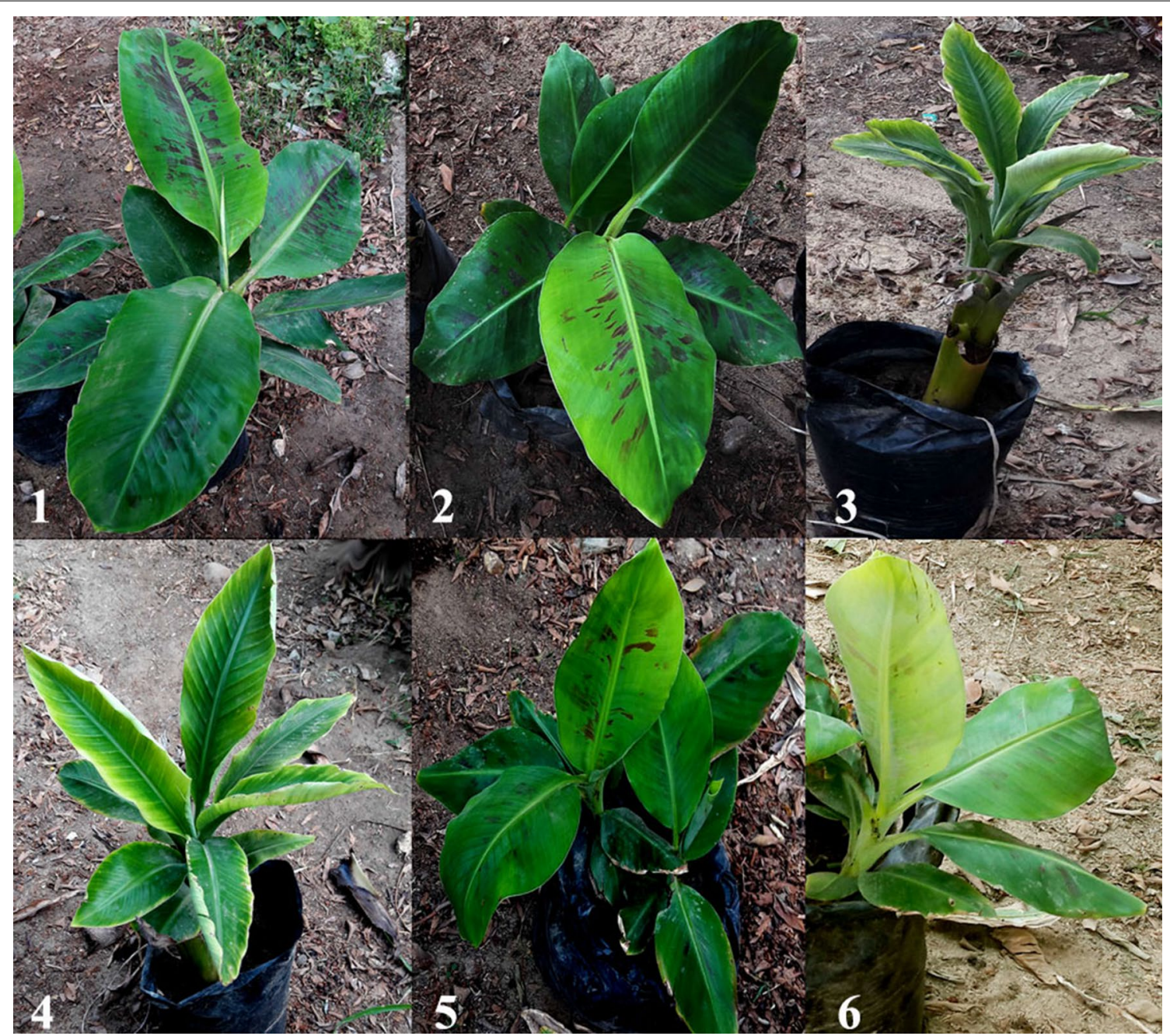

Fig. 1 Effect of treatment with AgNPs on BBTV infected banana plants, compared with healthy, nano- and viral controls. (1) Healthy control. (2) Banana plants treated only with 50 ppm AgNPs (nano-control). (3) Banana plants infected with BBTV (viral control), photoplate showing symptoms of dark green colored and form a "hook" shape on the midrib, reduced size, brittle of the leaves and gather at the top of the plant making a resetting shape. (4) Banana plant treated with 40 ppm AgNPs post-BBTV inoculation showing light green blade and light green streak on the midrib. (5) Banana plant treated with 50 ppm AgNPs post-BBTV inoculation showing no symptoms. (6) Banana plant treated with 60 ppm AgNPs post-BBTV inoculation showing phytotoxicity on the plant

AgNPs treatment post-BBTV inoculation induced a nonsignificant decrease in the content of carotenoids, compared with the healthy and nano-controls (Table 3).

\section{Bioactive components}

Results presented in Table 3 indicated differences in the bioactive components, due to treatment with AgNPs post-BBTV inoculation. It was observed that 40,50 and $60 \mathrm{ppm}$ AgNPs after viral infection led to a significant increase in total phenols and proline, compared to the healthy control. Besides, $50 \mathrm{ppm}$ AgNPs treatment postBBTV inoculation recorded the highest content of phenol and proline, compared with the healthy control. On the contrary, the healthy control was recorded with the lowest content of phenol and proline (Table 3).

\section{Oxidative enzyme activities}

The BBTV infected banana plants and sprayed with 40, 50 and $60 \mathrm{ppm}$ AgNPs scored significant variations in the oxidative enzyme activities, compared with the viral, nano- and healthy controls. The highest activities of POX and PPO isozymes were recorded in the banana plants treated with $50 \mathrm{ppm}$ AgNPs post-BBTV inoculation. However, the lowest activities of both enzymes were scored in the healthy control (Table 4). 


\begin{tabular}{|c|c|c|c|c|}
\hline Treatments & $\begin{array}{l}\text { NPs } \\
\text { conc.* } \\
\text { (ppm) }\end{array}$ & BBTV symptom & $\begin{array}{l}\% \text { of BBTV } \\
\text { infection }\end{array}$ & $\begin{array}{l}\text { ELISA } \\
\text { result } \\
(O D)^{* *}\end{array}$ \\
\hline Nano-control & 40 & Ns & - & 0.115 \\
\hline Nano-control & 50 & Ns & - & 0.113 \\
\hline Nano-control & 60 & Ns & - & 0.119 \\
\hline Healthy control & - & Ns & - & 0.093 \\
\hline Viral control & - & DG, HS, RS, BLB, RoS & 100 & 0.473 \\
\hline \multirow{3}{*}{$\begin{array}{l}\text { AgNPs post- } \\
\text { BBTV inocula- } \\
\text { tion }\end{array}$} & 40 & LGB, LGS & 63 & 0.117 \\
\hline & 50 & Ns & 35 & 0.110 \\
\hline & 60 & LYS & 45 & 0.132 \\
\hline
\end{tabular}

No symptoms (Ns), dark green (DG) color and form a "hook" shape, (HS) on the midrib, reduced size (RS), brittle of blade leaves (BLB), gather at the top of plant making a resetting shape (RoS), light green blade (LGB), light green streaks (LGS) on midrib of leaves and LYS = light yellow blade streak on the midrib. Reaction of ELISA = (negative control 0.093 and positive control 0.473)

NPs conc. ${ }^{*}=$ NPs concentration

ELISA result $(\mathrm{OD})^{* *}$, values are the means of three replicates

Table 2 The growth parameters of banana plants treated with AgNPs post-BBTV inoculation, compared with control

\begin{tabular}{llll}
\hline Treatments & $\begin{array}{l}\text { NPs conc.* } \\
\text { (ppm) }\end{array}$ & \multicolumn{2}{l}{ Plant growth parameters } \\
\cline { 3 - 4 } & & Dry weight $\mathbf{( g )}$ & Leaf area $\mathbf{( c m}^{\mathbf{2}} \mathbf{y}$ \\
\hline Healthy control & - & $6.5 \mathrm{c}$ & $130.2 \mathrm{~b}$ \\
Nano-control** & 50 & $7.2 \mathrm{~d}$ & $135.2 \mathrm{~b}$ \\
Viral control & - & $3.8 \mathrm{a}$ & $70.1 \mathrm{a}$ \\
AgNPs Post BBTV & 40 & $6.3 \mathrm{c}$ & $145.2 \mathrm{C}$ \\
inoculation & 50 & $6.7 \mathrm{c}$ & $154.2 \mathrm{~d}$ \\
& 60 & $5.3 \mathrm{~b}$ & $132.7 \mathrm{~b}$ \\
LSD & & 0.54 & 10.6 \\
\hline
\end{tabular}

Values are the means of three replicates

Means within the same column and treatment followed by the same letter are not significantly different according to Duncan $(P \leq 0.05)$

NPs conc. ${ }^{*}=$ NPs concentration

Nano-control ${ }^{* *}=$ The best concentration recorded the lowest of infection rate and non-toxic to the plants

\section{DNA fingerprinting between treated and untreated banana plants RAPD analysis}

RAPD was used to evaluate effect of silver nanoparticle at the genomic DNA level as an antiviral agent against BBTV, compared with the control plants (Fig. 2 and Table 5). Genomic DNA extracted from the banana leaves of the healthy, nano-, viral controls and test (BBTV infected ones and sprayed with 50 ppm AgNPs) were amplified using seven RAPD primers. A total of 73 amplified bands, ranging from 130 (RAPD-5) to $1400 \mathrm{bp}$ (RAPD-6) were recorded using the seven RAPD primers.
The number of amplicons per primer varied from eight (RAPD-2 and RAPD-3) to 14 (RAPD-4). Forty-six bands out of the 73 loci were monomorphic (63.01\%) and 27 reproducible bands were polymorphic (36.99\%). The RAPD-4 scored the maximum polymorphism with $71.43 \%$ (Table 5). On the contrary, RAPD-5 displayed the minimum polymorphism (9.09\%). This study showed that nano-control and banana plants sprayed with $50 \mathrm{ppm}$ AgNPs after BBTV inoculation induced four amplified fragments of $+910,+605,+493$ and $+900 \mathrm{bp}$, using primers RAPD-1, RAPD-3, RAPD-4 and RAPD7 , respectively. On the other hand, 17 out of the 73 were unique bands (23.29\%) (Table 5). Furthermore, the viral control scored positive and negative markers of $(-200 ;+252 ;+273$ and $-950 \mathrm{bp}),(+900 \mathrm{bp})$ and (+200 and $-1100 \mathrm{bp}$ ), using primer RAPD-1, RAPD-4 and RAPD-6, respectively. Moreover, the nano-control recorded two specific bands of +792 and $+475 \mathrm{bp}$, using RAPD-4 and RAPD-7, respectively. Besides, the banana plants treated with $50 \mathrm{ppm}$ AgNPs after BBTV infection exhibited eight specific bands with molecular sizes of (+730), (+310; -400; $-500 ;-530 ;-600$ and $+692 \mathrm{bp})$ and $(+1400 \mathrm{bp})$, using primer RAPD-1, RAPD-4 and RAPD-6, respectively (Table 5).

\section{SRAP profiles}

Five SRAP primers amplified genomic DNA extracted of the healthy, nano- and viral controls and ones treated with $50 \mathrm{ppm}$ AgNPs post virus inoculation. A total number of 40 amplicons were detected using five SRAP primers (Fig. 3 and Table 6). The number of loci varied from 100 bp primers (SRAP-1, SRAP-2 and SRAP-4) to $1400 \mathrm{bp}$ (primer SRAP-5). The number of amplified fragments per primer varied from 6 (SRAP-5) to 9 (SRAP-1 and SRAP-2). Twenty-five out of 40 were monomorphic (62.50\%), 15 fragments were polymorphic (37.50\%). The highest number of loci was recorded in primers SRAP-1 and SRAP-2 (nine loci), while the lowest number of bands was found in primer SRAP-5 (six fragments). The SRAP-5 scored the highest polymorphism with $50 \%$, followed by primer SRAP-2 (44.44\%). In contrast, primer SRAP-1 scored the lowest polymorphism (22.22\%). In addition, the nano-control and banana plants treated with $50 \mathrm{ppm}$ AgNPs after BBTV infection exhibited two amplicons of +150 and $+400 \mathrm{bp}$, using primers SRAP-4 and SRAP-5, respectively. On the other hand, 13 out of the 40 were specific markers (32.5\%) (Table 6). Moreover, the healthy control recorded three molecular markers of $-110 ;+420$ and $+1400 \mathrm{bp}$, using SRAP3, SRAP-4 and SRAP-5, respectively (Table 6). Besides, banana plants treated with $50 \mathrm{ppm}$ AgNPs post BBTV infection displayed eight markers with molecular sizes $(+414$ and $+700 \mathrm{bp}),(+390 ;-410 ;+692$ and $+710 \mathrm{bp})$, 
Table 3 Effect of AgNPs on phytochemicals content of BBTV infected banana plants by ANOVA, compared with the control

\begin{tabular}{|c|c|c|c|c|c|c|}
\hline \multirow[t]{2}{*}{ Treatments } & \multirow{2}{*}{$\begin{array}{l}\text { NPs conc.* } \\
\text { (ppm) }\end{array}$} & \multicolumn{3}{|c|}{ Plant photopigments (mg/g Fresh wt.) } & \multirow{2}{*}{$\begin{array}{l}\text { Phenol (mg/g dry } \\
\text { wt) }\end{array}$} & \multirow{2}{*}{$\begin{array}{l}\text { Proline } \\
\text { (mg/g dry } \\
\text { wt) }\end{array}$} \\
\hline & & Chla & Chl b & Carotenoids & & \\
\hline Healthy control & - & $20.87 b$ & $18.15 b$ & $6.20 \mathrm{a}$ & $6.32 \mathrm{a}$ & $1.60 \mathrm{a}$ \\
\hline Viral control & - & $18.75 a$ & $16.47 a$ & $5.94 a$ & $7.89 \mathrm{~b}$ & $2.15 \mathrm{C}$ \\
\hline Nano-control** & 50 & $20.25 b$ & $19.17 b$ & $6.75 \mathrm{a}$ & $7.45 b$ & $2.15 \mathrm{c}$ \\
\hline \multirow[t]{3}{*}{ AgNPs post-BBTV infection } & 40 & $18.24 a$ & $16.87 a$ & $7.65 b$ & $11.45 d$ & $1.95 b$ \\
\hline & 50 & $19.94 b$ & $18.50 \mathrm{~b}$ & $7.1 \mathrm{~b}$ & $11.68 d$ & $2.25 \mathrm{c}$ \\
\hline & 60 & $17.43 a$ & $16.75 a$ & $6.12 \mathrm{a}$ & $10.13 c$ & $2.21 \mathrm{C}$ \\
\hline L.S.D & & 1.24 & 1.34 & 1.12 & 1.4 & 0.12 \\
\hline
\end{tabular}

Means within the same column and treatment followed by the same letter are not significantly different according to Duncan $(P \leq 0.05)$

NPs conc. ${ }^{*}=$ NPs concentration

Nano-control ${ }^{* *}=$ The best concentration recorded the lowest of infection rate and non-toxic to the plants

Table 4 Effect of AgNPs treatment on the activities of peroxidase and polyphenol oxidase (unit/g. Fresh wt./hour) in BBTV infected banana plants by ANOVA, compared with the control

\begin{tabular}{llll}
\hline Treatments & $\begin{array}{l}\text { NPs conc.* } \\
\text { (ppm) }\end{array}$ & \multicolumn{2}{l}{ Antioxidant enzymes } \\
\cline { 3 - 4 } & & POX (U/g FW) & PPO (U/g FW) \\
\hline Healthy control & - & $1.245 \mathrm{a}$ & $0.213 \mathrm{a}$ \\
Viral control & - & $1.275 \mathrm{~b}$ & $0.253 \mathrm{a}$ \\
Nano-control** & 50 & $2.645 \mathrm{~d}$ & $0.313 \mathrm{~b}$ \\
AgNPs post-BBTV & 40 & $2.540 \mathrm{~d}$ & $0.383 \mathrm{c}$ \\
inoculation & 50 & $2.826 \mathrm{e}$ & $0.472 \mathrm{e}$ \\
& 60 & $2.275 \mathrm{C}$ & $0.433 \mathrm{~d}$ \\
L.S.D & & 0.028 & 0.038 \\
\hline
\end{tabular}

Values are the means of three replicates

Means within the same column and treatment followed by the same letter are not significantly different according to Duncan $(P \leq 0.05)$

NPs conc. ${ }^{*}=$ NPs concentration

Nano-control $^{* *}=$ The best concentration recorded the lowest of infection rate and non-toxic to the plants

(+ $821 \mathrm{bp})$ and (+500 bp), using primers SRAP-1, SRAP2, SRAP-3 and SRAP-4, respectively (Table 6). Furthermore, the viral control scored two negative markers of -930 and -505 bp, using primers SRAP-3 and SRAP-5, respectively (Table 6).

\section{Discussion}

Nanoparticles developed to nanostructures, had variable shapes and the size of the particles ranged from 1 to $100 \mathrm{~nm}$. Silver nanoparticles (AgNPs) have been exploited in the agriculture system against plant viruses (Elbeshehy et al. 2015; El-Dougdoug et al. 2018). The current study was carried out to evaluate the efficiency of silver nanoparticles for suppression of BBTV infection in banana plants. The treatment of BBTV infected banana plants with AgNPs was applied three days after BBTV inoculation (post-infection treatment). Generally, the post-infection treatment with $50 \mathrm{ppm}$ AgNPs led to the suppression of virus replication and an important decrease in the rate of infection with BBTV (36\%). These results were confirmed by DAS-ELISA. These findings suggested that AgNPs are effective antiviral factors, namely direct-acting antivirals (DAAs). These results were also confirmed in the study by Kuo et al. (2009) and Galdiero et al. (2011) which mentioned that AgNPs work as antiviral and antimicrobial agents. In addition, treatment of the plants with AgNPs post $24 \mathrm{~h}$ of virus inoculation gave the most effective results due to a decrease in virus concentration and the percentage of infection. In contrast, zero or weak reduction in virus concentration and percentage of infection were obtained when AgNPs were sprayed at the pre-viral infection (Speshock et al. 2010). Toshikazu (1999), Galdiero et al. (2011) and Narasimha et al. (2012) found that the BBTV concentration, percentage of infection, and disease severity were at low incidence when AgNPs were sprayed before six days of infection. This may be due to the inability of the AgNPs to activate the induced systemic resistance of the plant against BBTV infection. AgNPs inhibited replication of the virus when AgNPs particles size less than the virus size. Elbeshehy et al. (2015) reported that Bean yellow mosaic virus (BYMV) symptoms were observed when plants were treated with AgNPs after zero time from the virus inoculation (with viral inoculum sap). On the other hand, plants treated by AgNPs before $72 \mathrm{~h}$ from virus inoculation have not given any effect on viral infection, compared with other silver nanoparticles treatments. Khandelwal et al. (2014) observed the presence of reaction between AgNPs and virus genome, a direct reaction 


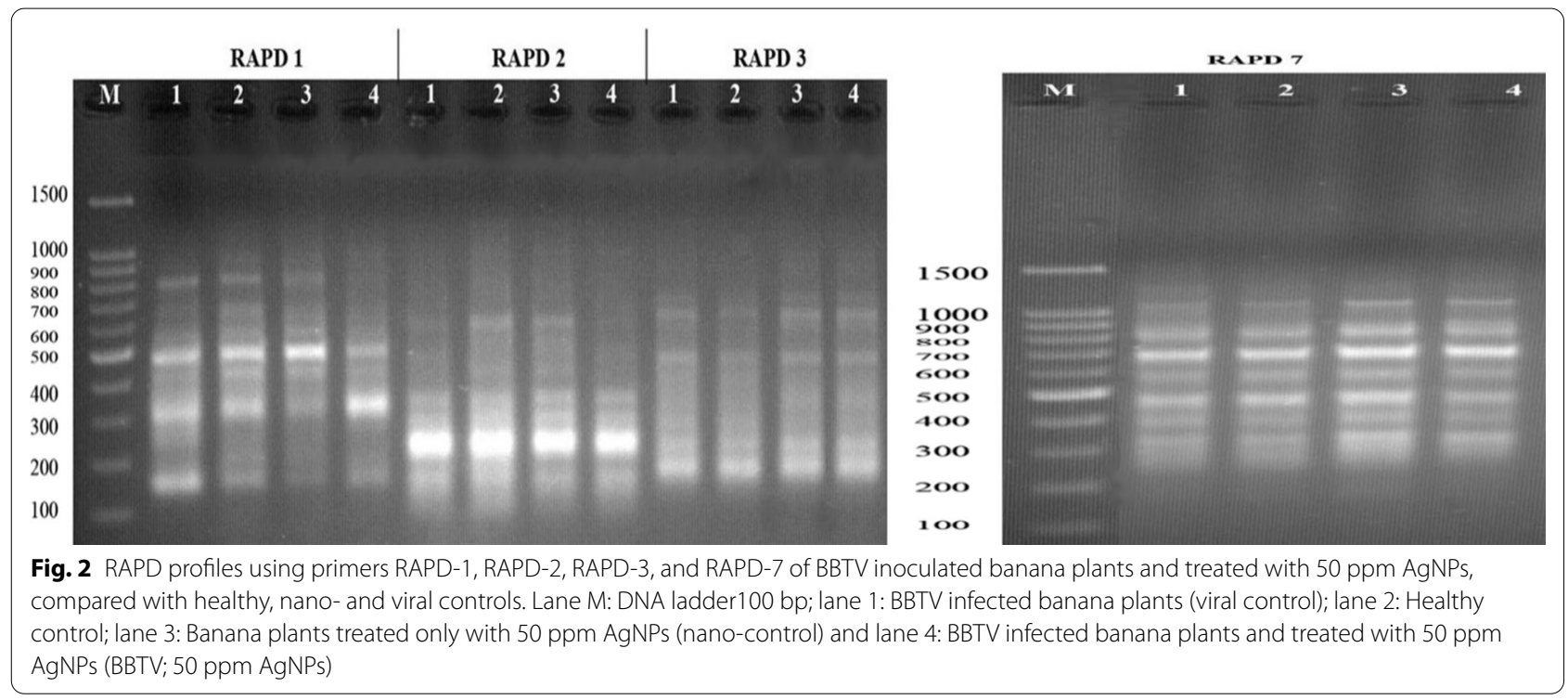

Table 5 RAPD analysis of BBTV infected banana plants and treated with 50 ppm AgNPs, compared with healthy, nanoand viral controls

\begin{tabular}{|c|c|c|c|c|c|c|c|c|}
\hline Primer code no & $\begin{array}{l}\text { Nucleotide } \\
\text { sequence } \\
\text { of primers }\end{array}$ & $\begin{array}{l}\text { Size range } \\
\text { of the scorable } \\
\text { loci (bp) }\end{array}$ & Total loci & $\begin{array}{l}\text { No. } \\
\text { of monomorphic } \\
\text { loci }\end{array}$ & $\begin{array}{l}\text { No. } \\
\text { of polymorphic } \\
\text { loci }\end{array}$ & $\begin{array}{l}\% \\
\text { Polymorphism }\end{array}$ & Unique loci & $\begin{array}{l}\text { Molecular size } \\
\text { of markers (bp) }\end{array}$ \\
\hline RAPD-1 & GTTTCGCTCC & $191-950$ & 12 & 6 & 6 & 50 & 5 & $\begin{array}{l}-200 ;+252 ;+273 ;+ \\
\quad 730,-950\end{array}$ \\
\hline RAPD-2 & AACGCGCAAC & $181-680$ & 8 & 5 & 3 & 37.5 & 0 & - \\
\hline RAPD-3 & CCCGTCAGCA & $195-785$ & 8 & 6 & 2 & 25 & 0 & - \\
\hline RAPD-4 & GGACGGCGTT & $177-900$ & 14 & 4 & 10 & 71.43 & 8 & $\begin{array}{l}+310 ;-400 ;-500 ;- \\
\quad 530 ;-600 ;+692 ;+ \\
\quad 792 ;+900\end{array}$ \\
\hline RAPD-5 & AAGCCCGAGG & 130-910 & 11 & 10 & 1 & 9.09 & 0 & - \\
\hline RAPD-6 & AAGGCGGCAG & $200-1400$ & 10 & 7 & 3 & 30 & 3 & $+200 ;+1400 ;-1100$ \\
\hline RAPD-7 & GGACGGCGTT & $300-1050$ & 10 & 8 & 2 & 20 & 1 & +475 \\
\hline Total & - & $130-1400$ & 73 & 46 & 27 & 36.99 & 17 & - \\
\hline$\%$ & - & - & - & $63.01 \%$ & 36.99 & & 23.29 & - \\
\hline
\end{tabular}
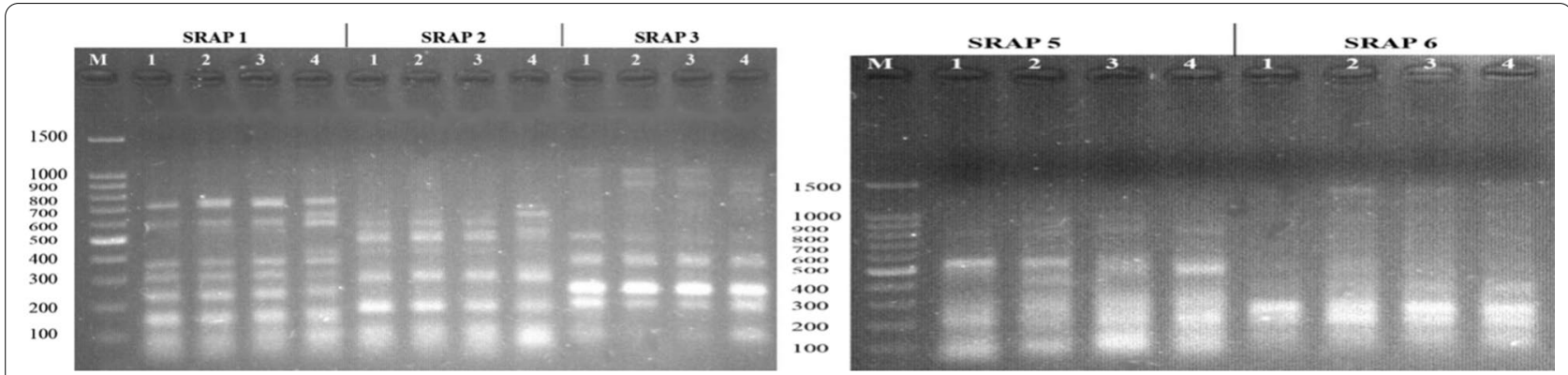

Fig. 3 SRAP profiles using primers SRAP-1, SRAP-2, SRAP-3, SRAP-5 and SRAP-6 of BBTV inoculated banana plants and treated with 50 ppm AgNPS, compared with healthy, nano- and viral controls. Lane M: DNA ladder100 bp; lane 1: BBTV infected banana plants (viral control); lane 2: Healthy control; lane 3: Banana plants treated only with 50 ppm AgNPs (nano-control) and lane 4: BBTV infected banana plants and treated with 50 ppm AgNPs (BBTV; 50 ppm AgNPs) 
Table 6 SRAP analysis of BBTV infected banana plants and treated with 50 ppm AgNPs, compared with healthy, nanoand viral controls

\begin{tabular}{|c|c|c|c|c|c|c|c|c|}
\hline $\begin{array}{l}\text { Primer } \\
\text { code } \\
\text { no }\end{array}$ & $\begin{array}{l}\text { Nucleotide } \\
\text { sequence } \\
\text { of primers }\end{array}$ & $\begin{array}{l}\text { Size range } \\
\text { of the scorable } \\
\text { loci (bp) }\end{array}$ & $\begin{array}{l}\text { Total } \\
\text { loci }\end{array}$ & $\begin{array}{l}\text { No. } \\
\text { of monomorphic } \\
\text { loci }\end{array}$ & $\begin{array}{l}\text { No. } \\
\text { of polymorphic } \\
\text { loci }\end{array}$ & $\begin{array}{l}\% \\
\text { Polymorphism }\end{array}$ & $\begin{array}{l}\text { Unique } \\
\text { loci }\end{array}$ & $\begin{array}{l}\text { Molecular size } \\
\text { of markers (bp) }\end{array}$ \\
\hline \multirow[t]{2}{*}{ SRAP-1 } & $\begin{array}{l}\text { F: TGAGTC } \\
\text { CAAACC } \\
\text { GGTAG }\end{array}$ & $100-716$ & 9 & 7 & 2 & 22.22 & 2 & $+414 ;+700$ \\
\hline & $\begin{array}{c}\text { R: GACTGC } \\
\text { GTACGA } \\
\text { ATT } \underline{\text { GTC }}\end{array}$ & & & & & & & \\
\hline \multirow[t]{2}{*}{ SRAP-2 } & $\begin{array}{c}\text { F: TGAGTC } \\
\text { CAAACC } \\
\text { GGTAG }\end{array}$ & $100-710$ & 9 & 5 & 4 & 44.44 & 4 & $+390 ;-410 ;+692 ;+710$ \\
\hline & $\begin{array}{c}\text { R: GACTGC } \\
\text { GTACGA } \\
\text { ATTCGA }\end{array}$ & & & & & & & \\
\hline \multirow[t]{2}{*}{ SRAP-3 } & $\begin{array}{c}\text { F: TGAGTC } \\
\text { CAAACC } \\
\text { GGTCC }\end{array}$ & 110-1010 & 8 & 5 & 3 & 37.5 & 3 & $-110 ;+821 ;-930$ \\
\hline & $\begin{array}{c}\text { R: GACTGC } \\
\text { GTACGA } \\
\text { ATTCAG }\end{array}$ & & & & & & & \\
\hline \multirow[t]{2}{*}{ SRAP-4 } & $\begin{array}{l}\text { F: TGAGTC } \\
\text { CAAACC } \\
\text { GGTCA }\end{array}$ & $100-808$ & 8 & 5 & 3 & 37.5 & 2 & $+420 ;+500$ \\
\hline & $\begin{array}{c}\text { R: GACTGC } \\
\text { GTACGA } \\
\text { ATT } \underline{C T G}\end{array}$ & & & & & & & \\
\hline \multirow[t]{2}{*}{ SRAP-5 } & $\begin{array}{l}\text { F: TGAGTC } \\
\text { CAAACC } \\
\text { GGTCA }\end{array}$ & $120-1400$ & 6 & 3 & 3 & 50 & 2 & $-505 ;+1400$ \\
\hline & $\begin{array}{c}\text { R: GACTGC } \\
\text { GTACGA } \\
\text { ATTAAT }\end{array}$ & & & & & & & \\
\hline Total & - & $100-1400$ & 40 & 25 & 15 & - & 13 & - \\
\hline$\%$ & - & - & - & 62.50 & 37.50 & - & 32.5 & - \\
\hline
\end{tabular}

with the virus surface proteins. In addition, AgNPs enter the plant cells, cause antiviral activity (with DNA or RNA) where they block the cellular factor or the viral vectors which help in the replication of the virus. Besides, AgNPs may attach to the viral genome so that no polymerase activity happens, and no generation of virus progeny takes place (Galdiero et al. 2011).

Results of this study indicate that $60 \mathrm{ppm}$ AgNPs caused negative effects on banana plants when was used with a concentration higher than a certain threshold. This result was also previously reported by Navarro et al. (2008) who found that the phytotoxic effect of AgNPs was linked to the impact of dissolved $\mathrm{Ag}^{+}$ions on the plants. In some cases, silver nanoparticles can be more toxic than free $\mathrm{Ag}^{+}$ions even at the same concentrations of $\mathrm{Ag}^{+}$. Tripathi et al. (2017) Adsorption of silver nanoparticles into plants may lead to inhibition of apoplastic trafficking by blocking pores and barriers in the cell wall or plasmodesmata, consequently prevent the apoplastic flow of water and nutrients (Geisler-Lee et al. 2014).

In the current investigation, treatment of banana plants with $50 \mathrm{ppm}$ AgNPs after BBTV infection recorded a significant increase in dry weight and leaf area, compared with BBTV infected banana plants (viral control). Besides, the concentrations of photosynthetic pigments (chlorophyll a and b) have not been affected in banana plants treated with $50 \mathrm{ppm}$ silver nanoparticles postBBTV inoculation. On the contrary, contents of chlorophyll $\mathrm{a}$ and $\mathrm{b}$ and carotenoids were reduced in $60 \mathrm{ppm}$ AgNPs treatment post-virus inoculation, which induces phytotoxicity changes on banana plants. These results were similar to those obtained by Dang Giap et al. (2018) who found that silver nanoparticles have positive effects on the growth of in vitro banana plants. The explants were cultured on shoot propagation and rooting media supplied with 1 and 3 ppm AgNPs, respectively. In particular, the content of chlorophyll for shoots cultured on 
medium containing AgNPs was higher than the control. These media were optimum for the growth of the shoots and roots. Salama (2012) observed that an increase in the AgNPs concentration from 20 to $60 \mathrm{ppm}$ led to a significant increase in shoot and root lengths, leaf area and chlorophyll in Zea mays L. and Phaseolus vulgaris L. plants. In this research, the highest contents of phenol and proline were indicated in $50 \mathrm{ppm}$ AgNPs post-BBTV infection, compared with the healthy control. These results were in agreement with Sameh (2005) stating that the content of phenolics was significantly increased in tomato plants infected with both Potato virus $Y$ (PVY) and Tomato mosaic virus (ToMV), compared with the healthy control. In addition, the content of phenols was significantly increased in broad bean plants treated by AgNPs. Balogun and Teraoka (2004) and Rai et al. (2009) mentioned that viral infection induces an increase in the activity of phenolics as a defense mechanism in plants. Besides, the accumulation of phenolic contents in plants treated with AgNPs was higher than virus-infected ones.

In the present study, the maximum activities of POX and PPO isozymes were scored in banana plants treated with $50 \mathrm{ppm}$ AgNPs after BBTV infection. However, the minimum activities of both enzymes were observed in healthy control. These results were an agreement with (Ma et al. 2015) who observed that the generation of excess reactive oxygen species (ROS) is induced by AgNPs in the plant cell. Many studies showed that ROS production is significantly increased in plants after exposure to AgNPs. There are four kinds of ROS produced in plant cells, involving singlet oxygen $\left({ }^{1} \mathrm{O}_{2}\right)$, hydrogen peroxide $\left(\mathrm{H}_{2} \mathrm{O}_{2}\right)$, superoxide $\left(\mathrm{O}_{2}{ }^{-}\right)$, and hydroxyl radical ( $\mathrm{HO})$.To prevent plant the oxidative damage induced by abiotic stress, it produces antioxidative enzymes like superoxide dismutase (SOD), catalase (CAT), polyphenol oxidase (PPO) and peroxidase (POX) which are most importantly involved in the scavenging system of ROS (Oidaira et al. 2000).

In this study, both RAPD and SRAP markers scored almost the same polymorphism 36.99 and $37.5 \%$, respectively. Furthermore, banana plants treated with $50 \mathrm{ppm}$ AgNPs post-BBTV inoculation exhibited new bands with different molecular sizes, using both RAPD and SRAP markers. Whereas, SRAP analysis gave the highest number of unique markers, compared with RAPD due to SRAP targets the coding region ORFs (open reading frames) (Liao et al. 2012). Exons are usually rich with GC contents and the 'CCGG' sequence in the core of the forward SRAP primers is designed to target such coding sequences (Shao et al. 2010; Kaewpongumpa et al. 2016). Besides, the RAPD primers amplify both coding and noncoding DNA sequence of the banana genome, but when it amplifies in one region it does not amplify in another, so decrease the possibility of amplifying the most polymorphic sequences (McGregor et al. 2000). Our results reveal that $50 \mathrm{ppm}$ AgNPs treatment post-virus inoculation induced a few changes in the banana plant genome. These changes were demonstrated on agarose gels by appearance or disappearance of some bands, compared with the healthy, nano, and viral controls. The appearance of novel loci may be ascribing modifications in the genomic DNA (Lee et al. 2013). However, the absence of DNA loci is characterized as DNA disintegration or rearrangements of genetic materials (Venkatachalam et al. 2017). Hassan et al. (2019) used RAPD and Direct amplification of minisatellite-region DNA (DAMD) techniques to detect DNA change in olive plants subject to different concentrations of silver or selenium nanoparticles. Changes in RAPD and DAMD profiles were determined based on the appearance or disappearance of loci. The polymorphism percentages in olive plantlets treated with 5 and $10 \mathrm{mg} / \mathrm{L}$ silver nanoparticles and 2.5 and $5 \mathrm{mg} / \mathrm{L}$ selenium nanoparticles were 41.10 to $41.46 \%$ using RAPD and DAMD profiles, respectively. New amplicons obtained from genomic DNA amplified from the nanoparticles treated olive plants indicted the dependency on the nanomaterial concentration and primer (Hassan et al. 2019).

In this work, it was observed that $50 \mathrm{ppm}$ AgNPs treatment post-virus inoculation induced low genetic toxicity at the genomic level in banana plants whereas, a number of disappeared DNA fragments were low. These findings suggest that the impact of AgNPs in BBTV resistance, whereas genotoxicity level of 50 ppm AgNPs in banana plants was low.

\section{Conclusions}

Banana crop faces many challenges, particularly viral diseases, e.g., BBTV. Nanotechnological approaches were used to generate resistance against plant viruses. In this study, $50 \mathrm{ppm}$ AgNPs treatment post-BBTV inoculation showed a significant reduction in BBTV replication when compared with non-treated ones. Besides, $50 \mathrm{ppm}$ AgNPs led to significant changes in growth parameters (dry weight and leaf area), oxidative enzymes, phenol and proline. However, from the molecular perspective, DNA change estimated using the RAPD and SRAP assays showed different patterns of loci between untreated and treated banana plants. These results are valuable in the future use of AgNPs as virucidal agents for crop protection.

\section{Abbreviations}

AgNPs: Silver nanoparticles; BBTV: Banana bunchy top virus; CAT: Catalase; CTAB: Cetyltrimethyl ammonium bromide; DAMD: Direct amplification of minisatellite-region DNA; DAS-ELISA: Double antibody sandwich-Enzyme 
linked immunosorbent assay; POX: Peroxidase; PPO: Polyphenol oxidase; RAPD: Random amplified polymorphic DNA; ROS: Reactive oxygen species; SOD: Superoxide dismutase; SRAP: Sequence-related amplified polymorphism.

\section{Acknowledgements}

The authors are thankful to the National Research Centre (NRC), Faculty of Science, Benha University and Faculty of Agriculture, Ain Shams University for their efforts.

\section{Authors' contributions}

All authors collected the theoretical details from the previous studies. Heba A. Mahfouze performed laboratory experiments such as oxidative enzymes, extraction of DNA, RAPD and SRAP markers, Noha K. El-Dougdoug achieved the reaction of BBTV strain with AgNPs concentrations on tested banana plants, determination of plant growth parameters, photosynthetic pigments and bioactive components and Sherin A. Mahfouze carried out statistical analysis and writing of the manuscript. All authors have read and approved the manuscript.

\section{Funding}

This study was not funded by any institution or any other entity.

\section{Availability of data and materials}

All data generated or analyzed during this work already exist in this published article.

\section{Ethics approval and consent to participate}

Not applicable.

\section{Consent for publication}

Not applicable.

\section{Competing interests}

The authors declare that they have no competing interests.

\section{Author details}

${ }^{1}$ Genetic Engineering and Biotechnology Research Division, Genetics and Cytology Department, National Research Centre, Dokki 12622, Egypt. ${ }^{2}$ Botany and Microbiology Department, Faculty of Science, Benha University, Benha, Egypt.

Received: 5 June 2020 Accepted: 11 October 2020 Published online: 04 December 2020

\section{References}

Allam EK, Othman BA, Sawy El, Thabet SD (2000) Eradication of Banana bunchy top virus (BBTV) and Banana mosaic virus (BMV) from diseased banana plants. Ann Agric Sci Cairo 45(1):33-48

Balogun OS, Teraoka T (2004) Time-course analysis of the accumulation of phenols in tomato seedlings infected with Potato virus $X$ and Tobacco mosaic virus. Biokemistri 16:112-120

Baram-Pinto D, Shukla S, Perkas N, Gedanken A, Sarid R (2009) Inhibition of herpes simplex virus Type 1 infection by silver nanoparticles capped with mercaptoethane sulfonate. Bioconjugate Chem 20(8):1497

Bates LS, Waldren RP, Teare ID (1973) Rapid determination of free proline for water stress studies. Plant Soil 39:205-207

Borsch T, Hilu KW, Quandt D, Wilde V, Neinhuis C, Barthlott W (2003) Noncoding plastid trnT-trnF sequences reveal a well resolved phylogeny of basal angiosperms. J Evol Biol 16(4):558-576

Bryaskova R, Pencheva D, Nikolov S, Kantardjiev T (2011) Synthesis and comparative study on the antimicrobial activity of hybrid materials based on silver nanoparticles (AgNPs) stabilized by polyvinylpyrrolidone (PVP). J Chem Biol 4(4):185

Clark MF, Adams AN (1977) Characteristics of the microplate method of enzyme-linked immunosorbent assay for the detection of plant viruses. J Gen Virol 34:475-483
Dang Giap DO, Thuy DTK, Trang NTH, Duoc NT, Tuan TT, Hieu DD (2018) Effects of nano silver on the growth of banana (Musa spp.) cultured in vitro. $J$ Vietnam Environ 10(2):92-98

Daniel HD, George CM (1972) Peach seed dormancy in relation to endogenous inhibitors and applied growth substances. J Am Soc Hortic Sci 97:651-654

Duncan DB (1980) Multiple range and multiple f effect of gamma radiation on growth and flowering of test. Biometrics 11:1-42

Elbeshehy EKF, Elazzazy AM, Aggelis G (2015) Silver nanoparticles synthesis mediated by new isolates of Bacillus spp., nanoparticle characterization and their activity against Bean yellow mosaic virus and human pathogens. Front Microbiol 6:1-13

El-Dougdoug KhA, Hazaa MM, Gomaa Hanaa HA, El-Maaty SA (2006) Eradication of banana viruses from naturally infected banana plants. 1-Biological and molecular detection of Cucumber mosaic virus and Bunchy banana top virus in naturally infected banana plants. J Appl Sci Res 2(12):1156-1163

El-Dougdoug KN, Bondok AM, El-Dougdoug KA (2018) Evaluation of silver nanoparticles as antiviral agent against ToMV and PVY in tomato plants. Middle East J Appl Sci 8(01):100-111

Elechiguerra JL, Burt JL, Morones JR, Camacho Bragado A, Gao X, Lara HH, Yacaman MJ (2005) Interaction of silver nanoparticles with HIV-1.J Nanobiotechnol 3:6

El-Sayed Eman H, Mahfouze SA, Shaltout AD, El-Dougdoug KhA, Sayed RA (2012) Chemical mutation of in vitro cultured shoot tip of banana cv. grand-nain for resistance some virus diseases. Int J Virol 8(2):178-190

Galdiero SFA, Vitiello M, Cantisani M, Marra V, Galdiero M (2011) Silver nanoparticles as potential antiviral agents. Molecules 16(10):8894

Geisler-Lee J, Brooks M, Gerfen JR, Wang Q, Fotis C, Sparer A, Ma X, Berg RH, Geisler M (2014) Reproductive toxicity and life history study of silver nanoparticle effect, uptake and transport in Arabidopsis thaliana. Nanomaterials 4:301-318

Hassan SAM, Mahfouze HA, Mahfouze SA, Abd-Allatif AM (2019) Genotoxicity assessment of nano-particles on micropropagated olive (Olea europaea L.) plants using RAPD and DAMD markers. Plant Arch 19(2):1985-1994

Hu JS, Wang M, Sether D, Xie W, Leonhardt KW (1996) Use of polymerase chain reaction (PCR) to study transmission of Banana bunchy top virus by the banana aphid (Pentalonia nigronervosa). Ann Appl Biol 128:55-64

Kaewpongumpa S, Poeaim S, Vanijajiva O (2016) Sequence-related amplified polymorphism (SRAP) analysis for studying genetic characterization of Bouea macrophylla. Biodiversitas 17(1):539-543

Khandelwal N, Kaur G, Kumara N, Tiwari A (2014) Application of silver nanoparticles in viral inhibition: a new hope for antivirals. Dig J Nanomater Biostruct 9(1):175-186

Kong FX, Hu W, Chao SY, Sang WL, Wang LS (1999) Physiological responses of mexicana to oxidative stress of $\mathrm{SO}_{2}$. Environ Exp Bot 42:201-209

Kuo WS, Chang CN, Chang YT, Yeh CS (2009) Antimicrobial gold nanorods with dual-modality photodynamic inactivation and hyperthermia. Chem Commun (Camb) 32:4853-4855. https://doi.org/10.1039/b907274h

Lee S, Chung H, Kim S, Lee I (2013) The genotoxic effect of ZnO and CuO nanoparticles on early growth of buckwheat, Fagopyrum Esculentum. Water Air Soil Pollut 224:1668

Li G, Quiros CF (2001) Sequence-related amplified polymorphism (SRAP) a new marker system based on a simple PCR reaction: its application to mapping and gene tagging in Brassica. Theor Appl Genet 103(2-3):455-461

Liao L, Guo Q, Wang ZL, Zhu Z (2012) Genetic diversity analysis of Prunella vulgaris in China using ISSR and SRAP markers. Biochem Syst Ecol 45:209-217

Lu L, Sun RW, Chen R, Hui CK, Ho CM, Luk JM, Lau GK, Che CM (2008) Silver nanoparticles inhibit Hepatitis B virus replication. Antivir Ther 13(2):253

Ma C, White JC, Dhankher OP, Xing B (2015) Metal-based nanotoxicity and detoxiffication pathways in higher plants. Environ Sci Technol 49:7109-7122

Mahfouze SA, Mahfouze HA, Mubarak DMF, Esmail RM (2018) Evaluation of six imported accessions of Lupinus albus for nutritional and molecular characterizations under Egyptian conditions. Jordan J Biol Sci 11 (1):47-56

Matta A, Dimond AE (1963) Symptoms of Fusarium wilt in relation to quantity of fungus and enzyme activity in tomato stems. Phytopathology 53:574-575 
McGregor CE, Lambert CA, Greyling MM, Louw JH, Warnich L (2000) A comparative assessment of DNA fingerprinting techniques (RAPD, ISSR, AFLP and SSR) in tetraploid potato (Solanum tuberosum L.) germplasm. Euphytica 113:135-144

Nair R, Varghese SH, Nair BG, Maekawa T, Yoshida Y, Kumar DS (2010) Nanoparticulate material delivery to plants. Plant Sci 179(3):154-163

Narasimha G, Khadri H, Alzohairy M (2012) Antiviral properties of silver nanoparticles synthesized by Aspergillus spp. Der Pharmacia Lettre 4:649-651

Navarro E, Piccapietra F, Wagner B, Marconi F, Kaegi R, Odzak N, Sigg L, Behra R (2008) Toxicity of silver nanoparticles to Chlamydomonas reinhardtii. Environ Sci Technol 42:8959-8964

Oidaira H, Satoshi S, Tomokazu K, Takashi U (2000) Enhancement of antioxidant enzyme activities in chilled rice seedlings. Plant Physiol 156:811-813

Papp I, Sieben C, Ludwig K, Roskamp M, Bottcher C, Schlecht S, Herrmann A, Haag R (2010) Inhibition of influenza virus infection by multivalent sialic-acid-functionalized gold nanoparticles. Small 6(24):2900

Potdar MV, Pawar KR (1991) Non-destructive leaf area estimation in banana. Sci Hortic 45:251-254

Rai M, Yadav A, Gade A (2009) Silver nanoparticles as a new generation of antimicrobials. Biotechnol Adv 27:6-83

Salama HMH (2012) Effects of silver nanoparticles in some crop plants, common bean (Phaseolus vulgaris L.) and corn (Zea mays L.). Int Res J Biotechnol 3(10):190-197

Sameh KH (2005) Effect of bean yellow mosaic virus on physiological parameters of Vicia faba and Phaseolus vulgaris. Int J Agric Biol. 1560-8530/07-2-154-57
Shao QS, Guo QS, Deng YM, Guo HP (2010) A comparative analysis of genetic diversity in medicinal Chrysanthemum morifolium based on morphology, ISSR and SRAP markers. Biochem Syst Ecol 38(6):1160-1169

Snedecor GW, Cochran WG (1980) Statistical methods, 7th edn. lowa State University Press, Ames

Speshock JL, Murdock RC, Braydich-Stolle LK, Schrand AM, Hussain SM (2010) Interaction of silver nanoparticles with Tacaribe virus. J Nanobiotechnol 8:19. https://doi.org/10.1186/1477-3155-8-19

Toshikazu T (1999) Antimicrobial agent composed of silica-gel with silver complex. Inorg Mater 6:505

Tripathi DK, Tripathi A, Singh S, Singh Y, Vishwakarma K, Yadav G, Sharma S, Singh VK, Mishra RK, Upadhyay RG (2017) Uptake, accumulation and toxicity of silver nanoparticle in autotrophic plants, and heterotrophic microbes: a concentric review. Front Microbiol 8:7. https://doi. org/10.3389/fmicb.2017.00007

Venkatachalam P, Jayalakshmi N, Geetha N (2017) Accumulation efficiency, genotoxicity and antioxidant defense mechanisms in medicinal plant Acalypha indica L. under lead stress. Chemosphere 171:544-553

Vernon LP, Selly GR (1966) The chlorophylls. Academic Press. New York and London. In: Kado CJ, Agrawal HO (eds) Virology. Van Nostrand Reinhold Company, New York

\section{Publisher's Note}

Springer Nature remains neutral with regard to jurisdictional claims in published maps and institutional affiliations.

\section{Submit your manuscript to a SpringerOpen ${ }^{\circ}$ journal and benefit from:}

- Convenient online submission

- Rigorous peer review

- Open access: articles freely available online

- High visibility within the field

- Retaining the copyright to your article

Submit your next manuscript at $\boldsymbol{\nabla}$ springeropen.com 